\title{
A Detailed Study on Environmental Sustainability in Knit Composite Industries of Bangladesh
}

\author{
Samit Chakraborty \\ School of Materials, the University of Manchester, Manchester, UK \\ Email address: \\ Samit_59@yahoo.com

\section{To cite this article:} \\ Samit Chakraborty. A Detailed Study on Environmental Sustainability in Knit Composite Industries of Bangladesh. American Journal of \\ Environmental Protection. Vol. 5, No. 5, 2016, pp. 121-127. doi: 10.11648/j.ajep.20160505.13
}

Received: July 25, 2016; Accepted: August 8, 2016; Published: September 8, 2016

\begin{abstract}
This research paper has illustrated different forms of contemporary sustainable measures that can be applied in knitwear manufacturing industries. Apart of discussing this aspect, the paper has also reported what types of sustainable measures are being adopted by the Bangladeshi garments industries while producing knitted garments. Different ways of introducing and maintaining sustainability in garments industry have been elaborately presented in this paper. The research has also described what kinds of difficulties usually impair industrialists in adopting or executing sustainable practices in producing knitted apparels. In order to collect the information the author visited five garments industries and conducted interview with key responsible persons of those industries. A questionnaire was prepared for interviewing them. Their answers have been discussed elaborately in this paper followed by a concise conclusion.
\end{abstract}

Keywords: Sustainability, Knitwear, Green, Organic Fibers, R\&D, Recycling, Dyeing, Finishing, Sewing

\section{Introduction}

Sustainability can be described as the potentiality of doing something without disturbing the environmental balance [13]. Sustainable product development can be defined as "development that meets the needs of the present without compromising the ability of future generations to meet their own needs" [16]. The sustainable apparel development features a system, which is based on environmentalism and sociological duty. A sustainable business model also includes several other aspects like lifespan of a product, the usage of natural resources in manufacturing processes, recycling, the effect of production methods on atmosphere etc [1]. Sustainability has become one of the major aspects in contemporary fashion world. It has become a burning issue in textile and garments industries. Consumers' raising consciousness regarding environmental sustainability has forced fashion industries to bring and ensure sustainability throughout the all processes and channels involved in manufacturing fashion products particularly apparels [15]. The consumption of apparel products is increasing day by day. The landfills are becoming filled with enormous amount of waste garments. Around $109 \mathrm{MJ}$ energy is consumed for producing a t-shirt $4 \mathrm{~kg}$ of is discharged fro the apparel industry while producing a single t-shirt. Thus the $\mathrm{CO}_{2}$ emitted during garments production is reinforcing the greenhouse effect [1]. Therefore ensuring environmental sustainability has become a prime concern in today's world. So the main objective of this research will be exploring different modes of sustainable practices, which can be introduced in apparel manufacturing plants. The research described what kind of the sustainable practices that are currently being undertaken by different knit composite industries of Bangladesh. Knitwear, which is widely consumed by consumers across the world, is creating huge impact in the lifestyle of people. The recent trend of fast fashion largely depends on knitwear fashion. It has been projected that this fashion would be bigger, popular and developed in the near future compared to the present market [9]. Knitwear industry is one of the dominating export oriented area in Bangladesh. In the year of 2014-15 the total export volume of knitwear has surpassed the export quantity woven products. The number of knit composite units has also increased within few years. There are also many industries, which have the spinning facility as well. These units generally contain knitting, dyeing, finishing, pattern making, cutting and sewing [2]. But these knitwear-manufacturing industries 
are now being questioned for their unsustainable working atmosphere. These industries are also being reprehended for not having sustainable supply chain management. For instance the amount of $\mathrm{CO}_{2}$ that is emitted in manufacturing a single t-shirt is considered as one of the largest contributors in increasing global temperature [1]. The biggest environmental pollution source in Bangladesh is its textile industries. Moreover, the dyeing and finishing industries are highly dependent on the usage of a vast amount of water. Apart of creating huge pressure on natural resources, different researches have also found disappointing results while investigating both untreated and treated wastewater used in many industries [5]. Since retailers and consumers are becoming more concerned about the sustainability of global environment, many knitwear-manufacturing industries in Bangladesh have taken revolutionary steps to induce sustainable manufacturing processes and green working environment in their production sites. Though these numbers are few compared to the total number of industries than those of which are not adopting sustainable production processes, the continuous effort to be sustainable will surely help those few industries to be bigger in further years and survive in the competition. So it brings an immense responsibility for the Bangladeshi knitwear manufacturers to introduce and ensure sustainability in all sections as early as possible for being a consistent leader in supplying apparel products to the entire fashion world. Moreover, there should be extensive researches on sustainable practices in knitwear manufacturing industries. Alongside the manufacturers, retailers, designers, government and consumers should also work together to ensure the establishment of an eco-fashion system as well as ecological balance [7]. Furthermore suppliers and retailers need to bring forth sustainable supply chain management, which will be transparent in its sourcing activities and responsible in applying sustainable measures in product designing, raw material selection, fabric production, coloration, finishing, packaging and most importantly in product development [13].

\section{Background}

Designers and retailers have been showing greater interest in developing knitted garments in recent years. Moreover, consumers now consider knitwear as more comfortable, cheaper and fashionable outerwear than other sources of fashion wear. In order to meet consumers' growing demand designers and retailers are now this circumstance has encouraged manufacturers from different parts of the world to establish knitwear-manufacturing industries. Knitwear includes products of some popular categories- t-shirt, polo shirt, tank top, sweatshirt and so many more [15]. The volume of production of these products is increasing gradually each fiscal year in Bangladesh. Apart of the export amount there is also a big domestic market of hosiery and knitwear in Bangladesh [2]. This dominating industry involves various manufacturing processes that require a gigantic amount of resources like energy, water, oil etc. on a daily basis, which is creating huge pressure on the environment. Furthermore, many of these processes release byproducts are harmful to environment. Therefore, it has become an emergency to establish sustainable production ambiance in knitwear manufacturing industries [22]. It has also been discovered that although consumers have become aware of environmental sustainability, the price factor still dominates consumers' purchase decision [19]. As a result low priced products are being manufactured and sold throughout in a greater extent compared to green products. Moreover, according to some retailers the concept of sustainability is still in inception phase, it has not reached to a mature stage. This consequence discourages retailers and thus manufacturers in adopting sustainable practices [10]. On the other hand environmentalists and scientists think that retailers and manufacturers should apply their own strategies to ensure a sustainable manufacturing ambiance for the betterment of the world [25].

\subsection{Sustainability in Knit Composite Industry}

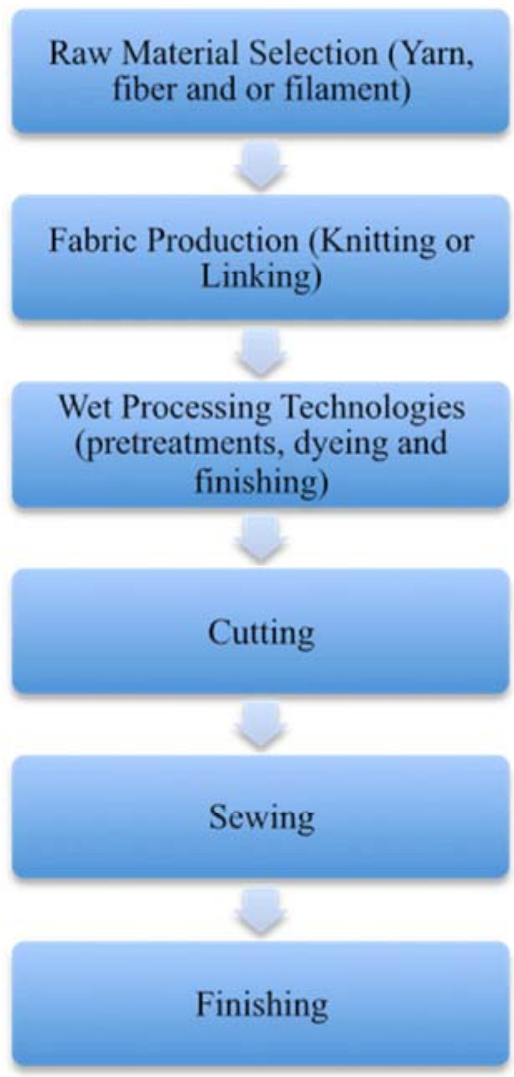

Figure 1. The flow process in knitwear manufacturing industry.

The main concept of sustainability is to produces green products, which are environment friendly and produced in such a way that, the manufacturing processes do not possess any negative impact on the physical components of environment- water, air and soil. Green products include different varieties of items that are either recycled or produced from organic raw materials or have required minimal energy during the production stages [10]. According to environmental science, sustainability is the design of human and production systems do not bring any detrimental effect on environment or 
slump natural resources and hence buttress ecological equilibrium [17] [20]. Bamboo fiber is. In general knitwear-manufacturing process includes sourcing and selection of raw materials (such as fiber, yarn and filament), fabric manufacturing (knitting or linking), wet processing technologies (pretreatments, dyeing and finishing), cutting, sewing and finishing, which have been briefly presented in figure 1. The subsequent illustrations will show how all of these operations can be turned into sustainable manufacturing processes [1] [15].

\subsection{Selection of Sustainable Raw Materials}

In apparel and textile industries the implementation of sustainability starts with the selection and purchase of eco-friendly materials. Cotton, viscose, polyester, cotton-polyester blend and nylon are such raw materials that are extensively used in making yarns, which are subsequently converted into knit fabric. Cotton, grey mélange and viscose are collected from natural sources. Different kinds of pesticides and herbicides used in cotton cultivation are harmful for the environment. Viscose or rayon produced from wood pulp contributes in deforestation and its production process requires toxic chemicals, which are also detrimental for nature. On the other hand, polyester and nylon are non-biodegradable synthetic fibers and produced from coal and petroleum. The production process of polyester, nylon and cotton-polyester blend consume huge energy. The nitrous oxide gas produced during producing polyester and nylon is 100 times toxic than green house gas $\mathrm{CO}_{2}$ [11]. Therefore designers, retailers and manufacturers should ensure the selection of sustainable raw materials while developing products. For instance use of organic cotton, hemp and linen are now being considered as the best sustainable alternatives of common natural fibers, because they require no or a little pesticides. Moreover, garments made from these types of fibers are likely to be not affected by chlorine bleaches and organic dyes [11]. Bamboo fiber is another better alternative collected from natural source, which is renewable and its production process does not require any hazardous chemical [21]. If designs and fabric structures require polyester then recycled polyester or recycled garments from polyesters can be better alternative to newly made polyester. Recently G-star raw has developed a new design of denim that is made from unused plastic bottles. This type of production requires less energy in comparison with the newly made polyester production process. Such initiative has been recognized as brilliant approach to sustainability [8].

\subsection{Ensuring Sustainability in Fabric Production}

The production of yarn and grey fabric usually require a huge amount of energy. So manufacturers should consider the environmental impacts seriously in each and every stages of clothing production Spinners can introduce new recycling technology, through which they can reclaim the fiber from the used products in order to convert them into yarn. 3D fabric production, body scanning and seamless knitting are few of the advanced technologies that would certainly reduce wastage of energy resources [1]. On the other hand the coloration of the fabric includes processes like pre-treatment, dyeing and finishing. Each of these operations is carried out through the application of various chemicals and reagents and requires a vast quantity of water and air compared to other processes involved in fabric manufacturing. Many of these chemicals are virulent and can pollute air, water and land [14]. The effluents produced during the pre-treatment, dyeing and finishing processes must be treated before disgorging these into water bodies like river or cannel closet to the industries. The noxious materials present in the untreated wastewater make the water unsuitable for being used. The living organisms of water and land (during the dry season) are severely affected and gradually destroyed. The wastewater containing $\mathrm{Cr}, \mathrm{Cu}$ and $\mathrm{Zn}$ can be harmful for environment and cause different skin diseases. If the dyed fabrics are not properly finished then the chemicals present in the garments then it also may create different skin related diseases in human body [5]. Therefore, manufacturers need to be sure about the sustainability concern. They must be careful during selecting the dyes and other chemicals. Besides of these, while treating the wastewater and removing the color the industries should ensure that they are using harmless agents and the parameters of the treated water fall in the range of purified water. Different physiochemical parameters such as $\mathrm{pH}$, BOD (Biological Oxygen Demand), COD (Chemical Oxygen Demand), TSS (Total Suspended Solids) and TDS (Total Dissolved Solids) of treated and untreated water will have to be measured to examine whether these parameters are within or beyond the standard limit set by the government and other environmental agencies [5]. Besides of these, use of natural or low-impact dyeing agents and harmless mordant can also be introduced in the factories to implement sustainable practices [3]. The chemicals used in the finishing are also hazardous and can pollute water [12]. Moreover, it requires a vast amount of water and steam to finish the dyed fabrics. Therefore, finishing process should be re-designed in order to reduce the redundant use of water and steam [15]. Different types of advanced mechanical finishing processes and biodegradable enzymes can be better alternatives of toxic chemicals that are used in finishing a dyed fabric [6] [13].

\subsection{Ensuring Sustainability in Garments Manufacturing}

The significance of environmental sustainability cannot be overlooked in garments manufacturing department as well. This department includes several other crucial departments like cutting, sewing and finishing. Fabric wastages vary in different proportions while preforming these operations. For instance, in cutting the fabric wastage may vary from $6-25 \%$ depending on the design of the garments [23]. During sewing and finishing wastage proportion are separately calculated. Thus a bulk amount of fabrics that were produced from the utilization of water, air, chemicals and other resources often remain unused at the end of the day. Since the most of the garments industries of Bangladesh are still dependent on manual labor, computerized cutting and assembly of garments 
would be a better alternative to conventional cutting and sewing method, which will reduce the fabric wastage to a greater extent [13]. Advanced machines like laser sewing machine can reduce fabric wastage and thus misuse of energy sources [1]. Industries should also be careful while selecting the solvents for finishing a garment. Additionally, they can introduce bio-enzymes instead of toxic chemicals while performing washable finishes [4].

\section{Methodology}

Qualitative methodology had been adopted to carry out this research. Five knit composite industries had been selected to prepare the report. CEOs and operation directors of those industries were requested to participate in a face-to-face interview with the author. They were interviewed separately and assured that their names' as well as company's name would not be revealed in this research paper. Therefore company names had been termed as A, B, C, D and E. A self-constructed questionnaire was prepared for the face-to-face interview. The questions were developed based on the literature review and inspired from Pasricha's research paper [24]. They also gave their ascent to record the interview. The author visited industries 'A', 'B', 'C', 'D' and ' $E$ ' in Narayanganj and Gazipur districts under Dhaka division. Although all of these factories were equipped with knitting, dyeing, finishing, printing, cutting, sewing and washing sections, they have variation in their production capacities, resources and facilities. For instance, industry ' $A$ ', ' $B$ ' and ' $C$ ' were classified as Tier 1 , whereas industries ' $D$ ' and ' $E$ ' were categorized as Tier 2 [18]. The questions developed for the questionnaire have been stated in the following table-
Table 1. Questionnaire for the respondents.

1. What does come to your mind when you think of sustainability? What specific actions are being taken by your industry as a part of sustainable practices?

-Do you use organic cotton, hemp, linen, recycled polyester?

2. -Do you reuse or recycle the wastewater or chemicals collected from dyeing and finishing?

-Do you use any machine that can be part of sustainability such as dyeing and finishing machine of any new technology, laser sewing machine, CAD?

3. What kind of research your R\&D is currently undertaking regarding sustainability?

4. What kind of hindrance do you face while implanting sustainability?

5. Do you think introducing sustainability can make you business more profitable?

6. Do you have any further advices?

\section{Results and Discussion}

The key people of each industry like operation director and CEOs of those industries was interviewed. They stated all the questions briefly. Initially they briefly narrated about sustainability and ecological importance of our society. Among them while the interviewees from industries ' $A$ ', ' $B$ ' and ' $C$ ' presented explicit statement on sustainability, the operation directors of industries ' $\mathrm{D}$ ' and ' $\mathrm{E}$ ' gave vague definition on sustainability. Their answers' on the other questions on sustainability have been presented in the table 2 . The author summarized the interviews individually and mentioned the pivotal points that are relevant to the research topic. While in few questions a similarity was found among the interviewees, in other queries there was huge disparity among their answers.

Table 2. Responses of the interviewees.

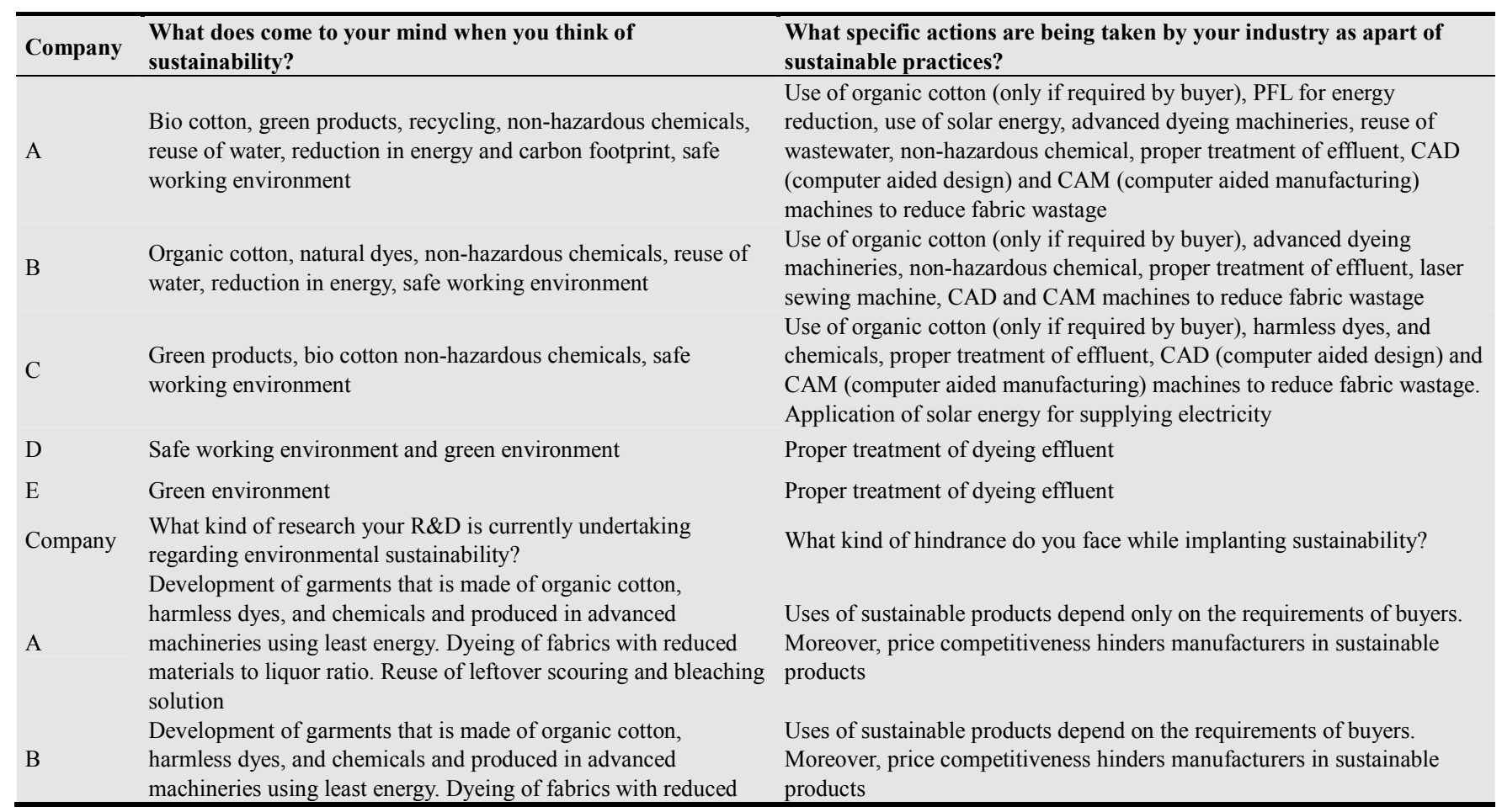




\begin{tabular}{|c|c|c|}
\hline Company & $\begin{array}{l}\text { What does come to your mind when you think of } \\
\text { sustainability? }\end{array}$ & $\begin{array}{l}\text { What specific actions are being taken by your industry as apart of } \\
\text { sustainable practices? }\end{array}$ \\
\hline & materials to liquor ratio & \\
\hline $\mathrm{C}$ & $\begin{array}{l}\text { Development of garments that is made of organic cotton, recycled } \\
\text { polyester, harmless dyes, and chemicals and produced in } \\
\text { advanced machineries using least energy }\end{array}$ & $\begin{array}{l}\text { Introducing sustainability depends on buyer's requirements. Whereas } \\
\text { practicing suitability increases overhead cost and CM (cost of making) } \\
\text { charge, buyer places order based on competitive price. }\end{array}$ \\
\hline $\mathrm{D}$ & No such initiative has been taken by the industry & $\begin{array}{l}\text { The company is not interested in practicing sustainability unless its buyer } \\
\text { asks for it. Moreover, operating and maintaining ETP is very expensive. }\end{array}$ \\
\hline $\mathrm{E}$ & No such initiative has been taken by the industry & $\begin{array}{l}\text { The company is not interested in practicing sustainability unless its buyer } \\
\text { asks for it. Moreover, operating and maintaining ETP is very expensive. }\end{array}$ \\
\hline Company & $\begin{array}{l}\text { Do you think introducing sustainability can make your business } \\
\text { more profitable? }\end{array}$ & Do you have any further advices? \\
\hline A & $\begin{array}{l}\text { Yes sustainability can make a business lucrative by ensuring } \\
\text { proper use of energy and resources. Sustainability greatly } \\
\text { contributes in gaining retailers' assurance. }\end{array}$ & $\begin{array}{l}\text { Consumers and retailers should come out of the tendency of cheap price } \\
\text { and more consumption. Besides, they should grow an intension of paying } \\
\text { more for green products and using a garment for at least } 30 \text { items. }\end{array}$ \\
\hline B & $\begin{array}{l}\text { Yes sustainability can make a business profitable by adopting } \\
\text { different sustainable means. }\end{array}$ & $\begin{array}{l}\text { Consumers and retailers should come out of the tendency of cheap price } \\
\text { and more consumption. }\end{array}$ \\
\hline $\mathrm{C}$ & $\begin{array}{l}\text { Yes sustainability can make a business profitable by adopting } \\
\text { different sustainable means. }\end{array}$ & $\begin{array}{l}\text { Retailers should advertise and promote about sustainability in a wide } \\
\text { spread range. }\end{array}$ \\
\hline $\mathrm{D}$ & $\begin{array}{l}\text { It will not make any difference. The increased price of the } \\
\text { product will discourage consumers to buy more. }\end{array}$ & $\begin{array}{l}\text { Retailers, manufacturers, governments and NGOs should establish a single } \\
\text { system, which will ensure retailers are showing interest in paying more for } \\
\text { green garments and manufacturers are maintaining sustainability }\end{array}$ \\
\hline $\mathrm{E}$ & It will not make any difference & $\begin{array}{l}\text { Retailers, manufacturers, governments and NGOs should establish a } \\
\text { system, which will ensure retailers are showing interest in paying more for } \\
\text { green garments and manufacturers are maintaining sustainability }\end{array}$ \\
\hline
\end{tabular}

As per the interview with company ' $A$ ' the author had reached to few distinct points. This industry is fully committed to sustainable manufacturing environment. The CEO presented a clear concept of sustainability. $\mathrm{He}$ and his company are well concerned about the importance of sustainability and ecological balance. Their authoritative management along with the R\&D always tires to bring new innovation in manufacturing knitwear. On the other side, since their production is based on retailers' demand, they cannot use sustainable raw materials especially bio cotton or recycled polyester all the time. Apart of this they, they ensure the use of bio-enzymes, and harmless dyes and chemicals. Regular observation of ETP, decolorization and reuse of wastewater, and reduction of energy and carbon footprint are their strict commitments to environmental sustainability. Environmentalists and global retailers are expressing their satisfactions towards these sustainable practices [15]. The operation director of company ' $\mathrm{B}$ ' also gave a clear explanation of sustainability and showed their participation in environmental sustainability programs. The company strictly monitors the use of harmless dyes and chemicals, treatment of effluent and $\mathrm{CO}_{2}$ emission. It has installed advanced dyeing, finishing and sewing machineries to reduce fabric wastage. As per buyer's requirements they also ensure that their nominated suppliers or spinners are using organic cotton while producing the yarn. In some circumstances they also import organic yarn from abroad to ensure the best quality. Both of the companies ' $A$ ' and ' $B$ ' had admitted that the price competitive business and retailers' conventional requirements of cheap garment products are the biggest obstacle in ensuring sustainability in all phases of manufacturing. Alike companies ' $A$ ' and ' $B$ ' the director of operation of company ' $\mathrm{C}$ ' also stated their commitment towards sustainability. This industry is currently establishing a project of solar system, which will supply electricity to few parts of the whole plant. They strictly monitor the use of harmless dye agents and regular treatment of effluent. Besides, their industrial engineering and production departments work so efficiently to reduce fabric wastage. They use bio cotton yarn only when buyers or retailers place any such particular order.

Both of the companies ' $D$ ' and ' $E$ ' had shown less interest towards the practice of sustainability. Apart of the regular treatment of effluent they did not take any step towards sustainability. Even they are least concern about the use of organic fiber, nonhazardous dyes and chemicals, reduction of fabric wastage and reuse of waste materials. They also claimed that since their buyers or customers did not require any of those sustainable practices, they did not pay attention towards the application of environmental sustainability.

From the above detailed study it can be stated that, the ' $A$ ' grade companies are more concern about environmental safety and sustainability. Apart of their retailers' requirements, they also design various strategies and implement them for the betterment of the environment. All of these industries believe that implantation of sustainable practices will be surely lucrative for their businesses and beneficial for their surrounding environment as well as mankind. On the other hand, companies like ' $\mathrm{D}$ ' and ' $\mathrm{E}$ ' do not have any present and future plan regarding environmental safety or ecological balance. Even their top managements do not have any clear conception about this phenomenon. They think sustainable practices will merely add value to their business. When the author described them about the importance of environmental sustainability and significance of protecting environment for the future generation they claimed that they would need the co-operation from retailers and government regarding this aspect since it will require a huge investment. Although many Bangladeshi Knitwear manufacturers are now becoming more concerned than earlier about sustainability issues for their own interests [13], these manufacturers claimed that only if the 
retailers agree to pay more for green products then they would adopt innovative strategies and modified production planning to ensure environmental sustainability.

The interviews also revealed that all in some phases of manufacturing these industries could not use sustainable raw material if their customers require different raw material, which they considered as an impediment in implementing environmental sustainability.

\section{Conclusion}

Garments industry is considered as the economic backbone of Bangladesh. This industry has a major contribution to the world economy as well. On the other hand, textile and garments industries are responsible for the environment pollution and ecological imbalance. Therefore, designers, researchers, manufacturers and retailers should work together to design new work model for ensuring environmental sustainability. This research has explored various types of sustainable practices that are currently being undertaken by the knitwear manufacturing industries. This project will help knitwear manufacturers of Bangladesh to show their progress in maintaining sustainable production processes. The research and development that have been already ensued will also help the industrialists to showcase their performance in building green working environment. The industries, which are less concerned and committed to sustainable practices, will also find this article beneficial for planning their business in near future. Moreover, designers, retailers, manufacturers, governments, social organizations and consumers will be benefitted from this research. It has also described how far these types of industries are committed to sustainability. The research has focused mainly on knit composite industries. Further researches can be conducted on woven textile mills. Besides of these, in future researcher can work on sustainability based on economic and social point of views.

\section{Acknowledgements}

The author acknowledges the support of the directors of operation and CEOs who happily gave their consent to participate in the interview.

\section{References}

[1] Allwood, JM, Laursen, SE, de Rodriguez, CM, and Bocken, NMP (2006). Well dressed? The present and future sustainability of clothing and textiles in the United Kingdom. Cambridge, UK: University of Cambridge, Institute of Manufacturing.

[2] BKMEA (2016). Bangladesh's Knitwear: BKMEA. [online] Available at: http://www.bkmea.com/bangladesh_knitwear.html [Accessed 1 Jun. 2016].

[3] Challa L. (2014) Impact of textiles and clothing industry on environment: approach towards eco- friendly textiles. http://www.fibre2fashion.com/. Accessed 28 June 2014.
[4] Chen, HL, \& Burns, LD. (2006). Environmental analysis of textile products. Clothing and Textiles Research Journal, 24 (3), 248-261.

[5] Dey, S. and Islam, A. (2015). A Review on Textile Wastewater Characterization in Bangladesh. Resources and Environment, 5 (1), pp. 15-44.

[6] ECOTEXTILES. (2011). Enzymes in textile processing. [online] Available at: https://oecotextiles.wordpress.com/2011/12/02/enzymes-in-tex tile-processing/ [Accessed 21 Jun. 2016].

[7] Fletcher, K. (2008). Sustainable Fashion \& Textiles. London, UK: Earthscan.

[8] G-star.com. (2014). G-Star RAW | RAW for the Oceans: the production process explained. [online] Available at: https://www.g-star.com/en_us/corporate/responsibility/news/ra w-for-the-oceans-production-process.htm [Accessed 5 Aug. 2016].

[9] Gao, J. (2009). Design on Knitwear Fashion. Asian Social Science, 5 (1).

[10] Gleim, M., Smith, J., Andrews, D. and Cronin, J. (2013). Against the Green: A Multi-method Examination of the Barriers to Green Consumption. Journal of Retailing, 89 (1), pp. 44-61.

[11] Greenchoices.org. (2016). Green Choices - Environmental impacts of clothing. [online] Available at: http://www.greenchoices.org/green-living/clothes/environment al-impacts [Accessed 21 Jun. 2016].

[12] Hannan, MA., Rahman, MA. and Haque, MF. (2011). An Investigation on Quality Characterization and Magnitude of Pollution Implications with Textile Dyeing Industries' Effluents using Bleaching Powder, DUET Journal, 1 (2), pp. 49-59.

[13] Islam, M. M. and Khan, M. M. R., (2014). Environmental sustainability evaluation of apparel product: a case study on knitted T-shirt. Journal of Textiles, 2014.

[14] Kadolph, SJ. (2010). Textiles. Upper Saddle River. NJ: Person Education Inc.

[15] Khan, M. and Islam, M. (2015). Materials and manufacturing environmental sustainability evaluation of apparel product: knitted T-shirt case study. Text Cloth Sustain, 1 (1).

[16] Lee, K., Mc Neill, D. and Holland, A. (2000). Global sustainable development in the twenty-first century. Edinburgh: Edinburgh University Press, p. 43.

[17] Lewis, VD, \& Chen, C. (2006). The life of a piece of cloth: developing garments into a sustainable service system. International Journal of Environmental, Cultural, Economic and Social Sustainability, 2 (1), pp. 197-207.

[18] Merk, J. (2014). The Rise of Tier 1 Firms in the Global Garment Industry: Challenges for Labour Rights Advocates, Oxford Development Studies, 42 (2) pp. 277-295.

[19] Mont, O. and Plepys, A. (2008). Sustainable consumption progress: should we be proud or alarmed? Journal of Cleaner Production, 16 (4), pp. 531-537.

[20] Muthu, SS, Li, Y, Hu, JY, Mok, PY, Ding, X, Wang, X, \& Weibang, C. (2010). Eco-impact of shopping bags: consumer attitude and government policies. Journal of Sustainable Development, 3 (2), pp. 71-83. 
[21] Nayak, L. and Mishra, SP, (2016). Prospect of bamboo as a renewable textile fiber, historical overview, labeling, controversies and regulation. Fashion and Textiles, 3 (1), pp. $1-23$.

[22] Niinimäki, K, \& Hassi, L. (2011). Emerging design strategies in sustainable production and consumption of textiles and clothing. Journal of Cleaner Production, 19 (1), pp. 1876-1883.

[23] Orbit (2007). EDIPTEX - Environmental assessment of textiles. [online] Available at:

http://orbit.dtu.dk/fedora/objects/orbit:110259/datastreams/file 7635219/content [Accessed 21 Jun. 2016].

[24] Pasricha, A. (2014). Exploration of the meaning of sustainability in textiles and apparel discipline and prospects for curriculum enhancement. $\mathrm{PhD}$, Iowa State University.

[25] Singh, K. (1999). Sustainable development: Some reflections. Indian Journal of Agricultural Economics, 54 (1), p. 6. 